\title{
Reflejos del futuro presente. Imágenes de los Estados Unidos en la prensa española de principios del siglo XX (1898-1914) ${ }^{1}$
}

por

\author{
David Corrales Morales ${ }^{2}$
}

Instituto de Historia, CCHS-CSIC

Este artículo se centra en las percepciones españolas sobre los Estados Unidos entre 1898 y 1914 a través del vaciado de algunas de las principales publicaciones de ese momento. Estableciendo una serie de ejes coincidentes -cultura, desarrollo científico-tecnológico, politica y sociedad-, el autor demuestra que la visión española no fue tan diferente a la de otros países, pues se vio condicionada por las valoraciones que se estaban realizando en Europa. Asimismo, el establecimiento de una extensa red de contactos en las redacciones de periódicos y revistas sirvió como canal de circulación de un conjunto de ideas y representaciones comunes sobre la potencia americana.

Palabras ClaVE: España; Estados Unidos; siglo XX; prensa; percepción; imagen.

Cómo Citar este artículo / Citation: Corrales Morales, David, "Reflejos del futuro presente. Imágenes de los Estados Unidos en la prensa española de principios del siglo XX (1898-1914)", Revista de Indias, LXXVII/270 (Madrid, 2017): 551-583, doi:10.3989/revindias.2017.018.

${ }^{1}$ Una versión preliminar de esta investigación fue presentada como trabajo de fin de máster en el Máster Interuniversitario en Historia Contemporánea (Universidad Complutense de Madrid) en 2014. Por esta razón, quiero expresar mi gratitud a José Antonio Montero Jiménez, director de dicho estudio y amigo en la actualidad. Asimismo, agradezco los comentarios aportados por algunos miembros del Tribunal, acicate personal para la redacción de este artículo.

2 david.corrales@cchs.csic.es ORCID iD: http//orcid.org/0000-0002-7696-7264. 


\section{INTRODUCCIÓN}

En los últimos años los innovadores planteamientos metodológicos y epistemológicos de la Historia de las Relaciones Internacionales han favorecido una comprensión más objetiva y transnacional sobre determinados procesos o fenómenos históricos, valorando el papel desempeñado por un gran número de actores y factores condicionantes ${ }^{3}$. Fruto de esta coyuntura, el campo de las imágenes y percepciones se ha consolidado como una nueva vía de estudio, la cual permite ahondar en el impacto que ha generado la posición hegemónica de los Estados Unidos en el imaginario colectivo de la sociedad europea desde principios del siglo XX.

A pesar de su repercusión actual en el mundo académico, los trabajos pioneros que evaluaron las opiniones extranjeras sobre la potencia americana se desarrollaron con un propósito práctico durante los primeros años de la Guerra Fría. En esos momentos, la amenaza comunista y la preocupación, cada vez mayor, acerca de la manera en que el resto de países veían a los Estados Unidos provocaron una fuerte polémica en el Congreso norteamericano, donde sus miembros discutían sobre la necesidad de impulsar el estilo de vida estadounidense fuera de sus fronteras, como herramienta para afianzar los intereses de Washington ${ }^{4}$. A raíz de este debate sobre la promoción cultural, Henry Steele Commager publicó el libro America in Perspective (1947), en el que se compilaban los testimonios de un gran número de personalidades europeas con el fin de valorar cómo había evolucionado la visión sobre esta nación desde el siglo XVIII hasta la actualidad ${ }^{5}$. Asimismo, la colección de ensayos As Others See Us (1959) recogía las impresiones ambivalentes que dominaban en países como Inglaterra, México o Egipto: "Americans had done remarkable things in production and they had technical 'know-how', but America itself was just a man-made mess. A giant with the head of a lout"6.

Si bien el auge de aquellas interpretaciones que defendían la imposición del sistema capitalista estadounidense sobre el resto de territorios relegaron a un segundo plano este tipo de análisis durante las décadas siguientes, los años noventa dieron paso a una segunda oleada de trabajos que, perviviendo hasta la actualidad, han ayudado a profundizar en la fascinación y animadversión que despertó esta potencia a lo largo de la última centuria. Mientras que la obra de C. Vann Woodward (The Old World's New World, 1991) sostiene que

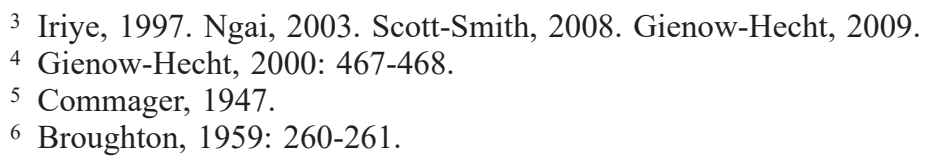

6 Broughton, 1959: 260-261. 
las estancias de numerosos visitantes europeos no lograron eliminar ciertos prejuicios y estereotipos a su regreso, el libro de David W. Ellwood (The Shock of America, 2012) esclarece la evolución que experimentó la imagen de los Estados Unidos como modelo de desarrollo en el Viejo Continente, reemplazando el fuerte desasosiego inicial por una visión positiva que consolidaba a este país como punto inexcusable de referencia ${ }^{7}$.

Junto a estas contribuciones académicas de carácter general, en los últimos años ha predominado el interés por las miradas particulares de diferentes territorios, aportando valiosos modelos de análisis. Uno de ellos se basa en la selección específica de determinadas personalidades como ejemplos representativos de las distintas naciones. Dentro de esta corriente, conviene señalar el estudio de Robert Frankel (Observing America, 2007), donde se valoran los vínculos culturales entre Inglaterra y los Estados Unidos durante la primera mitad del siglo XX a través de cuatro escritores británicos: William Thomas Stead, H. G. Wells, G. K. Chesterton y Harold J. Laski. Todos ellos fueron conscientes de la transformación experimentada por la potencia americana, asumiendo el liderazgo mundial que había ocupado el Imperio británico hasta ese momento. A pesar de mostrar respeto y afecto por esta nación, estas figuras consideraron que esta novedosa situación había eliminado la excepcionalidad del modelo político estadounidense e introducido mucho de los graves problemas que habían estado acosando al continente europeo desde décadas atrás ${ }^{8}$.

Por otro lado, existe una segunda tendencia que abarca de forma amplia la visión creada por una población determinada a través de un examen exhaustivo de diversas fuentes primarias, lo cual no evita el peligro de una generalización demasiado dogmática. Gracias a esta clase de estudios, se ha podido ahondar en las percepciones predominantes de países como Rusia, Alemania o Francia ${ }^{9}$. Respecto a este último caso, la obra Fascinations and Misgivings (2000) de Jacques Portes destaca dos sentimientos opuestos en la opinión pública francesa entre 1870 y 1914, admiración y temor. Mientras que autores como André Siegfried o Ernest Renan consideraron el modelo de desarrollo norteamericano como un buen ejemplo a seguir; la vulgaridad de la cultura estadounidense, los conflictos sociales o la aparente frialdad de la vida matrimonial fueron algunos de los temas recurrentes para expresar el desasosiego que producía el fenómeno de la americanización ${ }^{10}$. Así pues, este

\footnotetext{
7 Woodward, 1991. Ellwood, 2012.

8 Frankel, 2007: XV-XVI.

9 Ball, 2003. Diner, 1996. Guerlain, 1996.

10 Portes, 2000: 434.
} 
tipo de investigaciones inciden en el establecimiento de una imagen ambivalente, que también pudo estar presente en nuestra propia sociedad durante esos mismos años.

Más allá de un número reducido de trabajos que toman como objeto de estudio el origen y desarrollo de una fuerte animadversión hacia los Estados Unidos a lo largo del siglo $\mathrm{XX}^{11}$, las aportaciones académicas sobre el campo de las percepciones españolas son escasas y carentes de una amplia perspectiva histórica. Gran parte de las investigaciones realizadas han abordado de manera exclusiva el papel de la opinión pública durante la crisis de 1898 , examinando tanto la visión que se transmitía del enemigo norteamericano a través de distintas publicaciones periódicas como la interacción entre la diplomacia española y la prensa de difusión nacional en relación con el problema cubano ${ }^{12}$. A su vez, autores como Isabel García-Montón (Viaje a la modernidad, 2002) y César García Muñoz (Historia de un estereotipo, 2008) han recogido los testimonios de numerosos viajeros españoles -ingenieros, diplomáticos, científicos, intelectuales, etc.- con el único objetivo de establecer una serie de temas reiterativos que permitan ilustrar, primero, los choques culturales que producía la modernidad estadounidense y, segundo, las continuas comparaciones que se hacían entre América y Europa ${ }^{13}$.

Frente al panorama favorable que se desarrolla fuera de nuestras fronteras, esta carencia historiográfica contribuye a perpetuar ciertas interpretaciones sobre la excepcionalidad española. Por esta razón, el presente trabajo pretende demostrar que la visión española sobre los Estados Unidos no fue tan distinta a la de otras naciones europeas a principios del siglo XX. Aunque existieron características particulares como consecuencia de las propias circunstancias nacionales, lo cierto es que se produjo una traslación de diversas polémicas que estaban teniendo lugar en otras regiones europeas.

Dado que este campo de investigación resulta excesivamente amplio para abordarlo a lo largo de estas páginas, el objeto de estudio se ha delimitado en función de dos criterios básicos: uno temporal y otro temático. Las dos fechas que delimitan el marco cronológico de este artículo -1898 y 1914- son especialmente relevantes para las relaciones entre España y los Estados Unidos. El final del conflicto hispano-norteamericano dio paso a un nuevo rumbo en la orientación internacional de ambos países, al tiempo que los contactos bilaterales quedaron reducidos al ámbito comercial ${ }^{14}$. Una situación que no

\footnotetext{
11 Seregni, 2007. Fernández de Miguel, 2012.

12 Robles Muñoz, 1991. Schulze, 1998. Sevilla, 1998. Martínez de las Heras, 2001.

13 García Montón, 2002. García Muñoz, 2008.

14 Montero Jiménez, 2004: 24.
} 
impidió la construcción y transmisión de numerosas imágenes en la sociedad española ante la constante presencia de la potencia americana en los principales acontecimientos políticos, militares o económicos de ese período. Sin embargo, el estallido de la Primera Guerra Mundial conllevó tanto una intensificación de las relaciones entre ambas naciones como una radicalización de las percepciones dominantes, razón por la que se ha considerado oportuno no abordar esta nueva etapa. Por otro lado, la frecuente utilización de la prensa como principal soporte para la publicación de noticias e impresiones sobre los Estados Unidos favoreció su difusión entre sus lectores, repercutiendo en el imaginario colectivo de la sociedad. Por ello, se han seleccionado dos periódicos $-A B C$ y El Imparcial-y dos revistas -La España Moderna y Nuestro Tiempo- como principales referentes para este estudio ${ }^{15}$. No obstante, conviene realizar una serie de puntualizaciones que permitan comprender el entorno en el que se redactaron los artículos divulgados durante esos años.

Desde finales del siglo XIX, se produjo un importante avance en el ámbito periodístico español, que no sólo tuvo como resultado la aparición de algunos de los diarios más importantes, sino también el desarrollo de proyectos empresariales de envergadura, como la Sociedad Editorial de España, Prensa Española o la Editorial Católica ${ }^{16}$. Surgió una concepción periodística que aunaba prensa y negocio, al tiempo que modificaba aquellos antiguos planteamientos centrados en la rentabilidad política como objetivo exclusivo ${ }^{17}$. Sin embargo, este proceso de transformación conllevó una serie de limitaciones -falta de solidez económica, escasez de tiradas, etc.- que dificultaron la consolidación de un modelo de periodismo de masas, impidiendo un fuerte impacto de las publicaciones españolas. De hecho, numerosas revistas culturales, caracterizadas por su vitalidad, desaparecieron en un breve espacio de tiempo debido a su alto nivel de precariedad. Asimismo, el analfabetismo y la deficiente urbanización son algunas de las principales causas que ayudan a entender el perfil del público lector, perteneciente a las clases medias y altas ${ }^{18}$. A ello sumamos que la monopolización del mercado informativo por parte de grandes agencias internacionales como la francesa Havas tendió a uniformizar las noticias provenientes del extranjero. Salvo contadas excepciones, la ma-

15 Análogamente, se han consultado de manera complementaria otras publicaciones nacionales (todas ellas editadas en Madrid, así mismo también las de arriba), como La Correspondencia de España, La Época, Gedeón, La Lectura, Nuevo Mundo o Revista Contemporánea.

16 Sánchez Aranda y Barrera del Barrio, 1992: 169.

17 Ibidem: 205.

18 Seoane y Sáiz, 1998: 27. 
yoría de periódicos españoles no tenían corresponsales en las capitales de otros países.

Respecto a la autoría de aquellos escritos sobre la nación estadounidense, uno de los rasgos predominantes fue la presencia de un tipo indefinido. La participación de intelectuales o políticos en la redacción de numerosas publicaciones era un claro reflejo de la escasa profesionalización del periodismo durante los primeros años del siglo XX. A pesar del aumento progresivo de profesionales en la prensa española, la mayoría de los textos publicados eran firmados por un extenso abanico de expertos -ingenieros, juristas, economistas, sociólogos, diplomáticos, historiadores, etc.-. Como consecuencia de esta heterogeneidad, las percepciones sobre los Estados Unidos no estuvieron dominadas por una ideología política concreta; sobre este país escribieron conservadores, progresistas, republicanos o socialistas.

A su vez, la red de contactos que se estableció entre periódicos y revistas favoreció el afianzamiento de una serie de imágenes comunes, aspecto que fue posible gracias a la convergencia de dos factores clave. Primero, la mayoría de escritores no se limitaron a participar en una única publicación. Carlos Luis de Cuenca, Emilia Pardo Bazán, Manuel Troyano, Alejandro Sawa o Genero Alas son algunos de los casos más representativos. Segundo, un gran número de artículos fueron firmados por personalidades pertenecientes a la generación del 98 -como Unamuno o Azorín- o promotores del movimiento regeneracionista, entre los que cabe señalar a Rafael María de Labra, Rafael Altamira o Adolfo González Posada. Todos ellos abogaron por la europeización como vía para superar el atraso español. En definitiva, estos dos elementos contribuyeron a la creación de un conjunto de vínculos forjados a partir de contactos y experiencias comunes. De este modo, estas amplias redes se superpusieron a cualquier tipo de identidad individual y se convirtieron en canales de circulación de un abanico de ideas, juicios, imágenes y formas de representación sobre la potencia americana.

\section{LA FASCINACIÓN POR LA LITERATURA NORTEAMERICANA Y OTRAS FACETAS CULTURALES}

La cultura estadounidense -entendiendo como tal aquellas creaciones artísticas y literarias de mayor prestigio- despertó un enorme interés en las clases medias y altas españolas. Frente a la vigencia de ciertos prejuicios sobre la ausencia de gusto artístico en los Estados Unidos, los artículos difundidos pretendían reflejar que Europa y América no eran tan diferentes, pues en ambos territorios predominaba la misma preocupación por fomentar las 
«actividades superiores del espíritu» ${ }^{19}$. Fruto de esta tendencia, intelectuales como Ramón Pérez de Ayala pusieron en duda la opinión de quienes comentaban que los Estados Unidos no poseían ningún tipo de patrimonio histórico, defendiendo que esta nación representaba mejor que ninguna otra el sentido de la civilización ${ }^{20}$.

Resulta llamativo que gran parte de los trabajos sobre escritores estadounidenses tomaran como referencia textos difundidos previamente en países como Inglaterra, Alemania o Francia. En 1890, el periodista inglés William Thomas Stead fundó la Review of Reviews, que incluía un conjunto de reseñas sobre libros o revistas de diversa procedencia. Este formato influenció a numerosas publicaciones periódicas, que comenzaron a recoger en sus páginas crónicas y noticias de la prensa extranjera. Uno de los primeros precedentes en España vino representado por la sección «Revista de revistas» de La ESpaña Moderna, en la que el académico Fernando Araujo citaba artículos de La Revue, Revue Bleue, Nuova Antologia, Deutsche Revue, etc. Mientras que estas iniciativas ayudaron a transmitir una mirada favorable de la alta cultura americana, los diarios españoles siguieron prestando mayor atención a los avances modernizadores de esa sociedad.

Frente al desconocimiento que había predominado en períodos anteriores, los lectores españoles comenzaron a ser conscientes de la enorme riqueza que albergaba la literatura estadounidense:

La poesía moderna ha tenido en el suelo americano rico florecimiento: sueño fantástico, tierno y visionario, en Edgardo Poe; mirada curiosa [...] en Irving; armoniosa lamentación de alma nostálgica, en Longfellow; júbilo de vida real, en Holmes ${ }^{21}$.

Entre las figuras más populares, destacó Mark Twain, autor de clásicos como Las aventuras de Tom Sawyer (1876) o Un yanqui en la corte del rey Arturo (1899). La singularidad más apreciada de su obra era el humor, valorando su imaginación, alegría e ingenuidad como elementos indispensables en su dominio del género cómico ${ }^{22}$. Por ello, tras su fallecimiento en 1910, muchas revistas le rindieron homenajes que aludían a su carácter satírico ${ }^{23}$. Asimismo, algunos estudiosos, estableciendo comparaciones con el espíritu jocoso que caracterizaba a determinados escritores europeos, solían señalar

\footnotetext{
19 Nuestro Tiempo, febrero de 1914: 108.

20 Pérez de Ayala, 24 de enero de 1914: 2.

21 Araujo, octubre de 1905: 195.

22 Araujo, mayo de 1905: 191.

23 Nuevo Mundo, 7 de julio de 1910: 8.
} 
tanto la ausencia del tema sexual en sus libros como la presencia de un cierto idealismo romántico ${ }^{24}$.

Sin embargo, cabe preguntarse si esta admiración por el literato sólo era consecuencia de su producción literaria. A lo largo de su vida, Twain manifestó una férrea oposición a la anexión de territorios, y criticó el materialismo y la vulgaridad que predominaban en la sociedad norteamericana durante las décadas posteriores a la guerra civil -tema de gran relevancia en la prensa de ese momento-. Este tipo de declaraciones le alejaban de los estereotipos que la población española había forjado sobre los propios estadounidenses. A pesar de ello, un número reducido de textos continuaron perpetuando la cara más extravagante de este novelista, como las constantes peticiones de silencio que realizaba a aquellos ladrones que intentaban desvalijar su mansión ${ }^{25}$.

Otra gran personalidad a la que se prestó bastante reconocimiento fue Edgar Allan Poe. A raíz de la celebración del centenario de su nacimiento, Ángel Guerra, seudónimo utilizado por el periodista y político José Betancort Cabrera, escribió un ensayo donde criticaba la animadversión que seguía despertando este autor en su país natal, y mostraba cómo su carácter pesimista contrastaba con el puritanismo y la moralidad del espíritu americano ${ }^{26}$. Por esta razón, periodistas como Alejandro Sawa defendieron fervientemente que la producción de Poe se identificaba más con las corrientes europeas de ese momento ${ }^{27}$.

En contraposición a los continuos rumores que circulaban en los Estados Unidos sobre su temperamento desequilibrado y su adicción a la bebida, en España se difundió una imagen diferente que incidía en su perseverancia y en el valor de sus aportaciones artísticas: «Era pacífico, trabajador, cortés y animado. Trabajaba con método y asiduidad, desde las nueve de la mañana hasta las cuatro de la tarde» ${ }^{28}$. Además, la publicación de un artículo de Henri Potez en La Revue hizo que algunas revistas incidieran en la influencia que el escritor había tenido en los círculos literarios europeos, aspecto que quedaba reflejado tanto en las primeras obras de Jules Verne como en las novelas policíacas de Arthur Conan Doyle ${ }^{29}$.

Junto a estas figuras, la opinión pública española prestó atención a la labor literaria de otros importantes escritores que, al igual que los anteriores, pare-

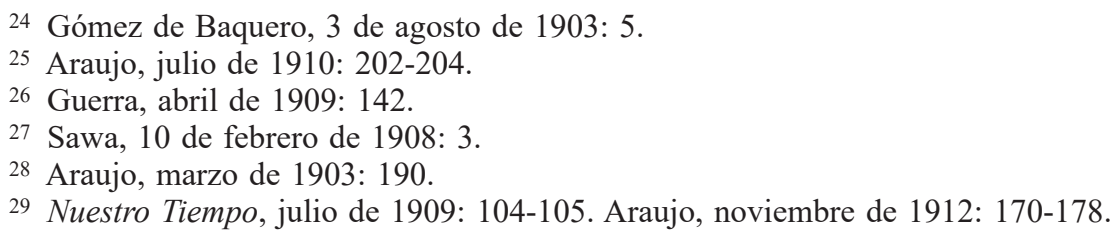


cían escapar de los esquemas conformados por el estereotipo de lo norteamericano. El propio Betancort valoró positivamente el alcance universal de los poemas de Walt Whitman, uno de los grandes representantes del llamado «Renacimiento americano»: «Para él no hay razas; no hay más que humanidad [...]. Esta visión amplísima pocos espíritus la han tenido con un generoso y ardiente cosmopolitismo ${ }^{30}$. Similares alabanzas recibió este poeta por parte de Miguel de Unamuno, quien mostró su entusiasmo por el verso no rimado y lírico de Whitman a la hora de reseñar su libro Hojas de hierba $(1855)^{31}$. Análogamente, numerosos eruditos halagaron las contribuciones realizadas por parte de dos escritoras norteamericanas que reflejaron algunas de las facetas negativas de esa nación: Harriet Beecher Stowe y Edith Wharton. Si la primera destacó por su lucha contra la esclavitud que reinaba en la América decimonónica, razón principal del enorme éxito que obtuvo La Cabaña del Tío Tom (1852) en el continente europeo; la segunda hizo un fiel retrato de la sociedad estadounidense, incidiendo en temas como la hipocresía y el materialismo ${ }^{32}$.

La fascinación por las creaciones literarias procedentes de este país se manifestó también en la aparición de relatos norteamericanos en las páginas de distintas revistas culturales: Una apuesta de millonarios y El pretendiente americano de Twain, El pais del placer de Wharton, Bloqueados por la nieve de Bret Harte, Viaje al Clondic y estudio sobre la vida de los buscadores de oro de Jeremiah Lynch, etc. Tomando como referencia los datos proporcionados por el vaciado de La España Moderna, se puede determinar un aumento gradual en la frecuencia de publicación de estas narraciones. Mientras que a finales del siglo XIX su presencia era nula, a partir de 1902 comenzaron a adquirir un mayor protagonismo, sobrepasando cuantitativamente a aquellos escritos de origen europeo en 1910 y 1913.

Esta visión positiva no se limitaba al ámbito literario, pues se extendía a campos como la pintura o la economía, tal y como refleja la traducción de alguno artículos sobre James McNeill Whistler, Henry George o el caricaturista Charles Dana Gibson ${ }^{33}$. A su vez, diversas publicaciones informaron con regularidad de las actividades culturales que se desarrollaban en ciudades como Chicago o Nueva York, aspecto al que contribuyó la difusión de textos

\footnotetext{
30 Guerra, junio de 1911: 26-27.

31 Unamuno, 6 de agosto de 1906: 3.

32 Nuestro Tiempo, octubre de 1911: 100-102. Terán, enero de 1910: 114-115.

33 Pazos y García, diciembre de 1912: 1-29. Araujo, octubre de 1908: 196-198. Nuestro Tiempo, septiembre de 1913: 86-87.
} 
procedentes de la prensa americana-American Review of Reviews, Atlantic Monthly, North American Review, etc.-.

El teatro americano adquirió mayor fama gracias a diferentes noticias que revelaban tanto los ingresos que obtenían algunos actores y productores, como las grandes sumas de dinero que se invertían en la construcción de edificios para las representaciones ${ }^{34}$. No obstante, el interés por los espectáculos teatrales quedó relegado a un segundo plano ante la presencia de los cinematógrafos, cuyo éxito de taquilla era indudable. Los estrenos de óperas como Parsifal de Richard Wagner o Salomé de Richard Strauss también aparecían en las páginas de las revistas nacionales, incluyendo fotografías de la puesta en escena. Aprovechando estos acontecimientos, las redacciones de diarios como $A B C$ encargaban a sus corresponsales la elaboración de crónicas en las que se narraba la recepción que estas obras habían tenido en los Estados Unidos. Aunque la mayoría de análisis mostraban el alto grado de exigencia del público norteamericano, en distintas ocasiones sirvieron para subestimar los gustos de la sociedad estadounidense, así como su conocimiento sobre las artes escénicas:

Los críticos yanquis andan, sobre poco más o menos, a la misma altura que la masa del público, y el público americano -me refiero al gran público, al popularsalió descorazonadísimo del estreno, porque le habían dicho que era una ópera americana, escrita sobre un libro americano, y esperaba encontrar alguna canción de negros o un cake-walk de esos que se pegan al oído... ¡Vayan ustedes a saber!35

En cuanto al fomento de la educación artística, no sólo se mencionaba el gran número de colecciones y museos que albergaban los Estados Unidos, sino también la promoción de otros medios de aprendizaje, como las bibliotecas ambulantes. Análogamente, se prestó atención a la labor de mecenazgo desempeñada por ciertos millonarios. Así, por ejemplo, se mencionó la donación de J. P. Morgan al Metropolitan Museum de un conjunto de esculturas, muebles y ornamentaciones que abarcaban desde el período gótico hasta el siglo XVIII ${ }^{36}$. Sin embargo, ninguna iniciativa despertó más admiración por el patrimonio cultural estadounidense que la inauguración de la Exposición de San Luis en 1904. Para la ocasión, las publicaciones españolas emplearon apelativos del estilo de «verdadero compendio de la historia de la humanidad» o «templo en el que oficiarán todas las naciones la misa santa del Progreso» ${ }^{37}$.

\footnotetext{
34 El Imparcial, 8 de octubre de 1905: 1.

35 Cadenas, 17 de diciembre de 1910: 5.

36 Nuestro Tiempo, marzo de 1910: 121.

$37 A B C, 30$ de enero de 1904: 2.
} 
Todo ello pretendía romper los prejuicios que todavía dominaban en la sociedad española sobre la inexistencia de una alta cultura en la nación norteamericana, objetivo al que también contribuyeron aquellos artículos centrados en las relaciones culturales entre ambos países. De hecho, la tarea realizada por los hispanistas estadounidenses era valorada como una «misión humanitaria y civilizatoria», que contrastaba con la actitud de aquellos españoles que renunciaban a su pasado ${ }^{38}$. Como consecuencia de la fundación de la Hispanic Society, las revistas nacionales dedicaron numerosas páginas a narrar la vida de su fundador, Archer Milton Huntington, y a describir las ricas colecciones que albergaba su museo: «Tal vez valga más que esos peregrinos sepulcros se hayan arrancado a la desaparición [...] para ser expuestos, bien conservados y cuidados, a la admiración universal» ${ }^{39}$.

En definitiva, la difusión de noticias y artículos sobre estas manifestaciones culturales -literatura, pintura, teatro, exposiciones, etc.- demuestra la existencia de un sustrato de interés por las creaciones e iniciativas artísticas que estaban surgiendo al otro lado del Atlántico. Esta coyuntura favoreció un mayor entendimiento entre España y los Estados Unidos, que acabó facilitando los contactos culturales entre ambas naciones. Por ello, la transmisión de estas imágenes positivas a través de la prensa ayudó a crear las bases para una colaboración estrecha entre determinados sectores intelectuales de uno y otro país durante el primer tercio del siglo $\mathrm{XX}^{40}$.

\section{Mirando Al PRogreso. El modelo de DesarRollo estadounidense}

A pesar del entusiasmo por la alta cultura americana, las publicaciones periódicas también se hicieron eco de los avances modernizadores que se estaban produciendo en diferentes ámbitos -medicina, industria, medios de transporte, comunicación, etc.-, sirviendo así para efectuar una crítica velada a la situación de la ciencia y la educación en España. No obstante, esta visión de América como escenario privilegiado del progreso estuvo presente en otras naciones europeas, sin impedir la aparición paralela de las primeras reacciones negativas ante el fenómeno de la americanización. Prueba de ello son los artículos de procedencia extranjera que, ocupando las secciones de ciertas revistas, ayudaron a alimentar estas percepciones en la opinión pública española.

\footnotetext{
38 Nuestro Tiempo, septiembre de 1912: 105.

39 Brouta, marzo de 1909: 89.

40 Niño, 2005: 57-94.
} 
Las investigaciones estadounidenses en el terreno científico se multiplicaron durante este período, provocando que la prensa nacional difundiera los avances que se estaban aplicando al otro lado del Atlántico. Junto al interés por los planteamientos del psicólogo Herbert Woodrow o los innovadores estudios sobre tuberculosis u otras enfermedades mentales, la resonancia de las teorías de Darwin provocó que algunos artículos incidieran especialmente en las prácticas eugenésicas, cuyo objetivo era «determinar las reglas para que los individuos que nazcan estén lo mejor dotados física, intelectual y moralmente» ${ }^{41}$. Más allá de los innumerables progresos alcanzados en campos como la medicina y la biología, muchas noticias destacaron otros descubrimientos de carácter arqueológico y geográfico. Uno de los más llamativos fue el hallazgo del Polo Norte en 1909 por parte del explorador Frederick Albert Cook, cuyos avatares fueron narrados con profusión ${ }^{42}$.

A raíz de la rápida industrialización que había tenido lugar durante el último tercio del siglo XIX, aparecieron numerosos inventos que buscaban facilitar la vida de las personas, desde comida enlatada hasta cintas transportadoras para los automóviles. Según Pérez de Ayala, la invención de estos artefactos respondía al espíritu práctico de la civilización estadounidense, más preocupada por el bienestar social que por el mero cultivo cultural. Frente a las innovaciones de personalidades como Eli Whitney o Robert Fulton, el escritor criticaba la falta de inventiva española ${ }^{43}$.

En medio de este panorama, los descubrimientos de Thomas Alva Edison -la batería de acumuladores, la lámpara de incandescencia de filamento de carbón, el fonógrafo, etc.- se convirtieron en objeto de admiración por parte de los periodistas, así como el laboratorio que estableció en Nueva Jersey con el fin de suministrar nuevos productos: «Tan poderoso genio proporcionaba el pan a más de tres millones de almas y daba a ganar a industriales y comerciantes más de cinco mil millones de pesetas al año» ${ }^{44}$. Gracias a la labor de este empresario e inventor, comenzó a utilizarse la electricidad en beneficio humano y de la industria, cuestión valorada positivamente al informar de los congresos que se estaban celebrando sobre este tema, y del majestuoso alumbrado de exposiciones como la de Panamá (1913). Una imagen compartida por autores extranjeros como Jules Huret, cuya impresión sobre el espectáculo nocturno de Nueva York fue difundida por Fernando Araujo:

\footnotetext{
41 Araujo, febrero de 1914: 161.

$42 A B C, 28$ de septiembre de 1909: 15.

43 Pérez de Ayala, 26 de enero de 1914: 1; 30 de enero de 1914: 1.

44 Alrededor del Mundo, Madrid, 26 de mayo de 1909: 15.
} 
París, visto por la noche desde las alturas de Montmartre, no es nada en comparación de esto. Se diría que todas las estrellas del cielo han venido a colocarse sistemáticamente a trescientos metros de la mano ${ }^{45}$.

Respecto a las mejoras de las comunicaciones, las invenciones del telégrafo eléctrico y del teléfono no sólo transformaron las condiciones de vida de la población española, sino que también hicieron posible la organización de empresas a escala nacional e incluso internacional ${ }^{46}$. Por esta razón, la prensa anunciaba con regularidad la aparición de nuevos inventos mecánicos que ayudaban a estrechar las distancias geográficas ${ }^{47}$. Estrechamente conectadas con estas innovaciones, se produjeron mejoras en medios de transporte como el tranvía o el tren, generadores de importantes intereses económicos. La divulgación de publicaciones estadounidenses como The Tramway and Railway World o Poor's Manual of Railroads permitió conocer detalladamente la extensión de las vías ferroviarias o la incorporación de la tracción eléctrica en diversas ciudades ${ }^{48}$. En contraposición a las constantes dificultades del sistema ferroviario español, la competencia entre las diferentes compañías estadounidenses hacía que los viajes fuesen más rápidos y baratos. Algunos escritos mencionaban cómo éstas contribuían a fomentar la instrucción agrícola, así como la protección y repoblación de los bosques ${ }^{49}$. Del mismo modo, aparecieron referencias sobre aquellos avances que se estaban produciendo en la industria automovilística o en la aviación, donde adquirieron gran protagonismo los dirigibles. Fruto de este especial interés por el espacio aéreo, diversos periodistas alabaron los éxitos de los hermanos Wright, cuyo primer vuelo se produjo el 17 de diciembre de $1903^{50}$.

Por otra parte, los medios de comunicación norteamericanos también se presentaron como modelo para la prensa española. Si la rotativa había transformado la producción de los diarios, la creación de la linotipia supuso un gran avance en la composición de los textos. Al mismo tiempo que ésta se introducía en las imprentas, las redacciones estadounidenses comenzaron a incorporar paulatinamente las máquinas de escribir, alcanzando gran éxito el prototipo inventado por un grupo de ingenieros de la factoría Remington ${ }^{51}$.

\footnotetext{
45 Araujo, septiembre de 1904: 206.

46 Jones, 1996: 277. Para un estudio amplio sobre el desarrollo de las multinacionales americanas: Chandler, 1978: 70-133.

$47 A B C, 22$ de enero de 1903: 6.

48 Nuestro Tiempo, marzo de 1901: 154; julio de 1901: 95-96.

49 Nuestro Tiempo, marzo de 1914: 71-74.

50 ABC, 3 de agosto de 1909: 12; 1 de octubre de 1909: 14 .

51 Vílchez de Arribas, 2012: 37.
} 
Junto a esta serie de adelantos, el historiador Julián Juderías destacaba la libertad de prensa que existía en los Estados Unidos:

Allí hasta el más pobre dispone de los medios necesarios para adquirir un periódicos $[\ldots]$ todos quieren que el diario no sólo les informe, sino que les indique la línea de conducta que tienen que seguir, la manera en la que deben pensar ${ }^{52}$.

En cuanto a la publicidad, diferentes artículos señalaban los grandes presupuestos que muchas empresas destinaban a anuncios con el objetivo de favorecer el consumo de sus productos, aspecto que enlazaba con el sistema de ventas a distancia y con los innovadores medios de producción que se estaban desarrollando en la sociedad estadounidense en ese momento. Entre los temas más llamativos, cabe señalar la aparición de los carteles o la eficiencia de medios como el denominado «hombre-sándwich»o los anuncios luminosos ${ }^{53}$.

A pesar de que los españoles mostraron su asombro ante los progresos alcanzados en estos ámbitos, nada era equiparable al impulso que había adquirido la arquitectura americana, cuyo mejor ejemplo era la construcción de inmuebles subterráneos o rascacielos como los edificios Singer (1908) y Woolworth (1913). De hecho, algunos periodistas bromeaban sobre su altura, comentando que el único ideal de los neoyorquinos era «poner escollos a los aeroplanos y dirigibles en las altas regiones de la atmósfera» ${ }^{54}$.

Más allá de la modernización en ámbitos como el transporte o la comunicación, la educación superior estadounidense, caracterizada por su tendencia democrática y espíritu científico, se convirtió en punto inexcusable de referencia para los países europeos. El conocimiento y la investigación se patentaron a través de los centenares de colleges y universidades - públicas y privadas- situadas a lo largo del país: se crearon nuevas escuelas graduadas, se concedieron un mayor número de becas, los salarios y oportunidades de empleo aumentaron en las facultades, etc. Esta nueva vitalidad se reflejó en el incremento que experimentaron las inscripciones de nuevos estudiantes, especialmente en los campos técnicos, durante los primeros años del siglo $\mathrm{XX}^{55}$.

Ante este panorama tan favorable, los observadores franceses, impresionados por el funcionamiento del sistema universitario americano, trataron de averiguar si éste podría ser aplicado en su país ${ }^{56}$. Una visión que compartían

\footnotetext{
52 Juderías, enero de 1912: 84.

53 Araujo, agosto de 1912: 193.

54 ;Adelante!, Madrid, 25 de julio de 1911: 20.

55 Kevles, 1988: 219-221.

56 Portes, 2000: 228.
} 
personalidades británicas como Bertrand Russell o H. G. Wells, quien mostró su profunda admiración por la labor realizada por profesores de Harvard e instituciones similares ${ }^{57}$. Al igual que había sucedido al informar sobre otras facetas del modelo de desarrollo norteamericano, las publicaciones periódicas participaron activamente en la transmisión de esta imagen positiva a la sociedad española, sirviendo una vez más para establecer comparaciones desalentadoras con respecto a la situación educativa que pervivía al otro lado del Atlántico:

Todo concebido y ejecutado con grandiosidad y con espíritu práctico, de tal modo, que cuando se vuelve la vista a nuestras Universidades europeas, se siente uno humillado, haciendo el efecto de parientes pobres ${ }^{58}$.

Respecto al entorno escolar, la prensa valoraba tanto su organización como las asignaturas que se impartían en la escuela. Análogamente, se seguían con atención las iniciativas destinadas a consolidar la instrucción elemental en el mundo rural, como la concesión de transporte escolar gratuito a aquellos estudiantes de los pueblos más alejados o el fomento de las bibliotecas públi$\operatorname{cas}^{59}$. Otros titulares incidían en las mejoras de las condiciones higiénicas y alimenticias que habían experimentado muchos centros escolares del país ${ }^{60}$.

Conforme aumentaron las iniciativas dirigidas a garantizar la protección de los menores de edad y su desarrollo en un ambiente favorable, un gran número de artículos abordaron aquellos estudios científicos que estaban modificando sustancialmente el modo de conocer el mundo infantil (Child Study-Movement ${ }^{61}$. Dentro de este campo de trabajo, adquirieron enorme relevancia los escritos del psicólogo G. Stanley Hall (Adolescence, 1904) así como las teorías educativas del filósofo John Dewey (School and Society, 1899), que rechazaban el autoritarismo en las escuelas e instaban a su sustitución por un aprendizaje de carácter más práctico ${ }^{62}$. Estos planteamientos influyeron en pedagogos españoles como Francisco Ferrer o Fernando Sainz, quienes abogaron por una mejora de las condiciones de la infancia. Asimismo, la atracción que generó este movimiento a favor de la infancia también se plasmó en algunas noticias centradas en medidas legislativas, como la Ley de los Tribunales Tutelares de Menores (1899), que aceptaba la idea de que el

\footnotetext{
57 Frankel, 2007: 90.

58 Araujo, marzo de 1901: 185-186.

59 Nuestro Tiempo, febrero de 1902: 115.

60 Araujo, noviembre de 1903: 198-199. Nuestro Tiempo, junio de 1911: 111-113.

61 Araujo, marzo de 1901: 191-196.

62 Para un mayor conocimiento sobre las ideas de Dewey: Menand, 2001: 316-330.
} 
Derecho penal represivo no era el sistema más adecuado para conseguir frenar la delincuencia juvenil ${ }^{63}$. El éxito de este proyecto hizo que posteriormente se extendiera al continente europeo.

De este modo, los lectores españoles fueron conscientes de la posición privilegiada que ocupaban los Estados Unidos en el terreno del conocimiento y el progreso a través de diferentes publicaciones periódicas, que carecían de un marcado carácter ideológico. No obstante, esta admiración por el modelo de desarrollo norteamericano no sólo se limitó a reflejar lo que decían distintos artículos de procedencia europea, sino que sirvió para efectuar una crítica contra la deficiente situación de la ciencia y la educación en España. En otras palabras, este interés ayudó a alimentar algunos de los debates nacionales que se mantenían en los círculos intelectuales durante esos años.

\section{El SISTEMA POLÍTICO AMERICANO, ¿UN CASO EXCEPCIONAL?}

Los avances de la sociedad estadounidense también se reflejaban en el funcionamiento de sus instituciones políticas. Si bien algunos sectores tradicionalistas observaron con recelo el experimento democrático de ese país a lo largo del período decimonónico, lo cierto es que el régimen norteamericano supuso un enorme atractivo para una minoría ilustrada de españoles ${ }^{64}$. Por esta razón, pervivió una imagen positiva de los principios que teóricamente guiaban a la nación estadounidense ${ }^{65}$. A su vez, conviene insistir en que grupos minoritarios como los republicanos federalistas seguían valorando a los Estados Unidos como el principal modelo de referencia para el futuro desarrollo democrático de España. Fruto de esta coyuntura, se tradujeron libros como $E l$ Gobierno congresional (1885) de Woodrow Wilson o El triunfo de la democracia (1886) de Andrew Carnegie, al tiempo que aparecían una gran variedad de escritos en torno a determinados aspectos del modelo político de ese país -elecciones presidenciales, partidos políticos, etc. ${ }^{66}$.

Sin embargo, la difusión de artículos de opinión procedentes de revistas estadounidenses, entre las que destacaba North American Review, contribuyó a trasladar a este lado del Atlántico algunas de las polémicas que inquietaban a la sociedad americana. A raíz de los triunfos conseguidos por los demócratas en las elecciones de 1911, Nuestro Tiempo dio a conocer un ensayo del

\footnotetext{
63 El Imparcial, 29 de enero de 1911: 4.

64 Niño, 2005: 58.

65 Nuestro Tiempo, diciembre de 1913: 93-94.

66 Nuestro Tiempo, julio de 1908: 103-104; enero de 1914: 98-100.
} 
periodista George Harvey, en el que reflexionaba sobre los relativos éxitos de este partido: «Casi todas las grandes victorias democráticas son debidas únicamente a las divisiones y contiendas que, desde hace años, desgarran el partido republicano» ${ }^{67}$. Del mismo modo, determinados autores españoles continuaron señalando las limitaciones del sistema democrático norteamericano, y aprovecharon para establecer múltiples equiparaciones con respecto a la teoría del sistema representativo en la Monarquía constitucional:

Excepto en lo que se refiere al nombramiento de los funcionarios más elevados, el Presidente de los Estados Unidos goza de más prerrogativas que un Monarca Constitucional, y se diferencia de éste [...] en que, mientras el Monarca constitucional debe ser ajeno en absoluto a las luchas de los partidos y se mantiene en elevada esfera, atento muy especialmente a sancionar los cambios de política que demanda la opinión pública, manifestada en las elecciones o en otra forma, el Presidente americano es, ante todo y sobre todo, hombre de partido que va a ocupar la más alta magistratura de su país para desarrollar una política determinada ${ }^{68}$.

A medida que se iban poniendo de manifiesto los casos de corrupción que asolaban esta nación, la visión idealizada que había predominado comenzó a fragmentarse de manera paulatina. Las fiestas celebradas por distintos diputados, así como algunas de las exhibiciones que tenían lugar en la Cámara de representantes de Washington, pusieron en cuestión la seriedad y honradez de las instituciones norteamericanas ${ }^{69}$. Un proceso que se replicó en países como Francia e Inglaterra, donde este tipo de críticas dominaban desde el siglo XIX. Mientras el escritor Rudyard Kipling describía de manera peyorativa a aquellos políticos que había conocido en San Francisco, William Thomas Stead rechazó la perversión que caracterizaba al Gobierno de la ciudad de Chicago y a los dos partidos que luchaban por su control ${ }^{70}$. Por otra parte, aumentaron las noticias sensacionalistas que informaban sobre aquellas facetas más excéntricas de la política norteamericana, desde el protagonismo que adquirían las imágenes de los candidatos presidenciales, hasta la transformación de las campañas electorales en grandes espectáculos en los que participaban incluso animales ${ }^{71}$.

Los propios presidentes de los Estados Unidos no lograron escapar de esta visión estrafalaria. Así, por ejemplo, la prensa mencionó las habilidades coreográficas que mostraba William Howard Taft en algunas de sus recepcio-

\footnotetext{
67 Nuestro Tiempo, marzo de 1911: 100.

68 Cubillo, octubre de 1904: 83-84.

$69 A B C, 4$ de marzo de 1907: 2.

70 Frankel, 2007: 28.

71 Gabaldón, 2 de julio de 1908: 10.
} 
nes ${ }^{72}$. No obstante, ninguno despertó mayor fascinación en la opinión pública española que Theodore Roosevelt. Entre 1903 y 1914, el 61,62\% de las noticias que publicaba el periódico $A B C$ sobre la esfera política norteamericana se centraban exclusivamente en su figura. Así pues, no sería erróneo afirmar que su imagen consiguió englobar aquellas percepciones que se vislumbraban ante cuestiones como las acciones exteriores de la potencia americana, su sistema político o las características singulares de la sociedad estadounidense.

Roosevelt, que adquirió enorme prestigio tras su participación en la guerra hispano-norteamericana, se convirtió en uno de los principales representantes del progresismo a nivel estatal. Desde comienzos del siglo XX, este movimiento reformista destacó por la amplitud de sus preocupaciones: la regulación gubernamental de la economía, el saneamiento de las instituciones políticas, la prohibición de fabricar y vender bebidas alcohólicas, el sufragio femenino, la mejora de las condiciones laborales, etc. Ante la incertidumbre que despertaban la creciente concentración de la riqueza y el aumento de la corrupción, sus representantes se nombraron a sí mismos «guardianes del interés público» ${ }^{73}$. Por ello, la llegada de Roosevelt a la Casa Blanca supuso una redefinición de los objetivos del Ejecutivo norteamericano en favor de los intereses nacionales.

Cuando éste se convirtió en presidente tras el asesinato de McKinley en 1901, las publicaciones españolas difundieron escritos procedentes de revistas británicas, como The Fortnightly Review o The Nineteenth Century, en los que se alababa el carácter independiente y transparente de este político ${ }^{74}$. A pesar de que sorprendió gratamente el anuncio de una rectificación de la política aduanera y el fomento de una serie de reformas sociales, lo cierto es que la mayoría de autores españoles se mantuvieron cautelosos con respecto a la orientación de su política exterior, reiterando que seguirían vigentes las intervenciones imperialistas en América Latina ${ }^{75}$. Sin embargo, esta visión se modificó ligeramente debido a su mediación en la guerra ruso-japonesa.

Tras la entrega del Premio Nobel de la Paz en 1906, numerosas personalidades apoyaron esta decisión, aunque algunos como Francisco Mora continuaron recordando el pasado belicista de Roosevelt e insistieron en que este premio no se habría otorgado a ningún mandatario que hubiera estado gober-

72 Cavia, 9 de marzo de 1910: 1.

73 Jones, 1996: 341-342. Para un mayor conocimiento sobre el período progresista (The Progressive Era, 1895-1920): Hofstadter, 1955. Wiebe, 1967.

74 Aznar, noviembre de 1901: 97-102.

75 Canals, octubre de 1901: 7. 
nando en un país pacífico o menos relevante ${ }^{76}$. Mientras que a lo largo de los siguientes años pervivió este tipo de referencias a su tendencia militarista, resultan llamativos los ensayos de aquellos que confiaban en las buenas intenciones de sus acciones, recogiendo incluso la opinión del presidente sobre el conflicto cubano de 1898: «Los Estados Unidos nunca han estado preparados ni se prepararán jamás para una guerra. La guerra les coge siempre de sorpresa» ${ }^{77}$. Estas posiciones enfrentadas en torno a su figura volvieron a reflejarse a raíz de su visita a Madrid en 1914 para asistir a la boda de su hijo Kermit con Belle Willard -hija del embajador de los Estados Unidos en España-. Si bien algunos artículos de la prensa española señalaron el conocimiento que poseía de la cultura española, otros seguían criticando su participación en la guerra hispano-norteamericana.

Una de las polémicas que más interés causó durante su mandato fue la regulación de los trusts. A pesar de que distintos territorios habían aprobado leyes que prohibían estos monopolios desde 1880, esta reglamentación resultó poco efectiva. Más allá de sus constantes intentos por restringir las actividades de las grandes compañías, su mayor triunfo lo consiguió en 1904, momento en el que el Tribunal Supremo ordenaba la disolución de la Northern Securities Company, holding ferroviario organizado por J. P. Morgan y algunos de sus socios empresariales ${ }^{78}$. A partir de ese momento, se entablaron numerosos pleitos contra diferentes trusts norteamericanos -Standard Oil Company, American Tobacco Company, etc.-- La actitud inflexible manifestada por el presidente estadounidense respecto de este tema ocupó un gran número de titulares en los periódicos españoles, subrayando su oposición hacia aquellos que acumulaban elevadas fortunas ${ }^{79}$. Asimismo, prestigiosas personalidades como el académico Gabriel María Vergara no sólo apoyaron las acciones desempeñadas por Roosevelt, sino que también llegaron a establecer comparaciones con la propia situación nacional, afirmando que el peso de ciertas asociaciones y agrupaciones estaba impidiendo la iniciativa privada e individual en España ${ }^{80}$.

Los lectores españoles también fueron testigos de las innumerables extravagancias que aparecían en los diarios españoles sobre su vida, aspecto que contribuyó a emitir juicios de valor sobre el carácter norteamericano, el materialismo de su sociedad o los graves peligros que existían en sus ciudades.

\footnotetext{
76 Mora, 17 de agosto de 1906: 6.

77 Pérez de Ayala, 25 de abril de 1914: 3.

78 Norton, Katzman, et al., 1986: 607.

$79 A B C, 3$ de septiembre de 1906: 6.

80 Vergara, marzo de 1907: 271-273.
} 
Tras la elección de Taft como presidente de los Estados Unidos, Roosevelt decidió retirarse temporalmente de la política. Ante esta situación, se informó con regularidad de sus nuevos proyectos, como su intención de dedicarse al periodismo, y de sus actividades en el extranjero, desde sus viajes por Europa hasta la caza de leones y elefantes ${ }^{81}$. Aunque este tipo de escritos enfatizaban su talante diplomático y espíritu aventurero, tampoco renunciaban a transmitir algunos de los rumores que circulaban al otro lado del Atlántico: «Las partidas que organiza en su país tienen fama. [...] Malas lenguas dicen que le ponen las piezas como le ponían las carambolas a Fernando VII ${ }^{82}$.

Anunciada su nueva candidatura a la presidencia, la campaña electoral de 1912 se convirtió en una contienda entre tres participantes -Roosevelt, Taft y Wilson-, que dio buena muestra de las disputas que existían en la esfera política norteamericana. A pesar de su derrota, el intento de asesinato de Roosevelt contribuyó a consolidar su prestigio. Desde su llegada a la Casa Blanca, los rumores sobre posibles atentados contra su persona habían sido objeto de interés en la prensa española con el fin de reforzar la amenaza anarquista que existía en este país ${ }^{83}$. Por ello, las páginas de los periódicos detallaron el ataque que recibió en octubre de 1912 y las motivaciones de su agresor, alcanzando límites insospechados: «Dice que se le ha aparecido el presidente MacKinley y le ha ordenado que vengue su muerte, matando a Roosevelt, porque Roosevelt fue quien mató a MacKinley» ${ }^{84}$. Además, la decisión de no postergar el mitin que el candidato iba a celebrar esa misma tarde provocó muchas ovaciones por parte de los periodistas.

Así pues, podemos afirmar que la imagen transmitida de Roosevelt a través de las publicaciones españolas fue ambivalente. Se mantuvieron ciertos recelos hacia sus intervenciones exteriores, aunque numerosos comentaristas respaldaron tanto su férrea personalidad como muchas de sus decisiones políticas, especialmente la regulación de los trusts. Una valoración que coincidía con las manifestadas por académicos europeos como Guglielmo Ferrero. Este historiador italiano le calificaba como «representante de la nueva América que aspiraba a la dominación del universo», al tiempo que destacaba el valor de sus convicciones y su rechazo hacia posturas extremas ${ }^{85}$. Si bien se perpetuó una visión estrafalaria a la hora de abordar determinadas facetas de su vida privada, lo cierto es que esta clase de percepciones no se redujeron exclusi-

\footnotetext{
$81 A B C, 11$ de diciembre de 1908: 14. El Imparcial, 25 de marzo de 1909: 1.

$82 A B C, 3$ de julio de 1908: 7.

83 El Imparcial, 5 de junio de 1903: 3; 29 de noviembre de 1901: 1.

$84 A B C, 16$ de octubre de 1912: 5.

85 Nuestro Tiempo, junio de 1910: 128.
} 
vamente a la figura de Roosevelt, ya que trascendieron a distintos ámbitos de la población estadounidense, acentuando así las diferencias entre Europa y los Estados Unidos.

\section{LUCES Y SOMBRAS. RETRATO EXTRAVAGANTE DE UNA SOCIEDAD}

Frente a la existencia de una mirada positiva sobre su cultura y desarrollo científico, pervivieron una serie de prejuicios de carácter social que proyectaban una imagen de América como nación heterogénea, materialista, desalmada y peligrosa; tarea a la que contribuyeron la traducción de reportajes pertenecientes a revistas extranjeras -Review of Reviews, La Revue, Mercure de France, etc. - y la publicación de diarios de viaje como el del periodista francés Jules Huret (En América. De Nueva York a Nueva Orleans, 1905). De este modo, se pretendía reforzar la identidad de la propia población española y su vínculo con otras regiones europeas.

Uno de los aspectos que más llamaban la atención era la diversidad étnica, así como la capacidad de asimilación del país. Finalizada la guerra civil, se produjo un aumento de la inmigración, que excedió los treinta y seis millones de personas ${ }^{86}$. Diversos artículos señalaban la capacidad de estos individuos de adoptar una lengua y unos valores comunes como pueblo, aceptando este nuevo territorio como si fuera su país de nacimiento ${ }^{87}$. A pesar del establecimiento de este acuerdo común en medio de un espacio multicultural, la cuestión era examinada con preocupación, pues generaba problemas que podían poner en peligro la política interior y exterior de la nación -la discriminación racial, la diversidad de religiones, la concentración en ciudades industriales, etc. -88 .

En cuanto a la situación de la gente de color, los artículos juzgaban las desigualdades que todavía imperaban en la práctica, informando de los continuos linchamientos que se producían en localidades como Leesburg (Virginia) y Springfield (Ohio) ${ }^{89}$. Estos terribles sucesos provocaron que algunos autores denunciaran la hipocresía de los principios americanos y arremetieran contra el escaso interés que habían mostrado las autoridades estadounidenses por educar y alfabetizar a la población negra tras la abolición de la esclavitud (1865). Para ello, era habitual el empleo de frases humorísticas como «Amé-

\footnotetext{
86 Jones, 1996: 298-299.

87 Araujo, diciembre de 1903: 191.

88 ABC, 3 de julio de 1907: 4. Nuestro Tiempo, junio de 1912: 107-108.

89 El Imparcial, 15 de febrero de 1899: 1. ABC, 3 de marzo de 1906: 5.
} 
rica para los americanos, pero para los americanos que no sean de color» ${ }^{90}$. No obstante, el rechazo a esta discriminación se mantuvo en otros países europeos, tal y como refleja la difusión de ensayos de figuras tan relevantes como el explorador británico Henry Hamilton Johnston, quien curiosamente adquirió enorme prestigio por su participación en el reparto de África durante la segunda mitad del siglo XIX ${ }^{91}$.

Por otro lado, la libertad de creencias y la inexistencia de una autoridad en materia religiosa eran percibidas con cierta incredulidad y desconfianza. Frente a aquellas noticias que recalcaban el avance del catolicismo en los Estados Unidos, otras aludían al éxito de sectas como la «Iglesia del Dios vivo ${ }^{92}$. A diferencia del canon establecido por la Iglesia Católica, los planteamientos de estos grupos eran motivo de burla, al tiempo que se lamentaba el hecho de que muchas personas creyeran firmemente sus doctrinas. Una de las asociaciones más criticadas fue la llamada "Ciencia cristiana», producto de las enseñanzas de Mary Baker Eddy, quien recibió constantes reproches en los diarios españoles: «Ha conseguido reunir bastantes adeptos y no despreciable suma de dólares, muy útiles para ir pasando esta pícara vida mientras llega el inevitable tránsito a la fortuna ${ }^{93}$. Otros escritos abordaron las estafas que ponían en marcha predicadores y falsos profetas, aprovechándose del natural supersticioso de muchos millonarios ${ }^{94}$.

Respecto al funcionamiento y organización de la sociedad, un tema insistente era la independencia de la mujer. Una serie de artículos consolidaron ciertos estereotipos de carácter peyorativo, que pretendían reflejar su vulgaridad en contraposición a la elegancia que poseía cualquier dama europea: «Se las perdona su voz gangosa, la desenvoltura con que hablan desde lejos, y hasta la horrible costumbre que tienen de masticar goma» ${ }^{95}$. Análogamente, la prensa transmitió la enorme preocupación que existía en los círculos académicos norteamericanos ante el aumento progresivo de divorcios y la entrada de mujeres en el mundo laboral, pues temían una ruptura de la vida familiar tal y como era conocida hasta ese momento. La difusión de esta polémica provocó que autores como Edmundo González Blanco afirmaran que el honor femenino no existía en ese país, donde se

\footnotetext{
90 Rubiano, 25 de julio de 1906: 68. $A B C, 15$ de enero de 1908: 4.

91 Nuestro Tiempo, noviembre de 1910: 106-108.

$92 A B C, 5$ de marzo de 1904: 1. El Imparcial, 16 de febrero de 1912: 4.

93 Alfaro, 26 de junio de 1914: 4.

94 Araujo, enero de 1905: 193-197.

95 Araujo, mayo de 1903: 172.
} 
producían continuas separaciones conyugales o bodas sin el consentimiento paterno ${ }^{96}$.

La opinión sobre los trabajos que muchas jóvenes desempeñaban tampoco resultó muy favorable, criticando los bajos sueldos que cobraban o la poca integridad que demostraban al aceptar ciertas ocupaciones ${ }^{97}$. Este tipo de valoraciones se repitieron reiteradamente en Europa, aunque predominaron algunas desavenencias sobre la educación de las jóvenes estadounidenses. Si bien la opinión pública española rechazaba la formación que éstas recibían al considerarla desmoralizadora, el filósofo británico Bertrand Russell, quien dio varias conferencias en Bryn Mawr, quedó impresionado por la eficiencia y disciplina que imponía la presidente del college, Carey Thomas ${ }^{98}$.

En medio de esta coyuntura, la extensión de los derechos de la mujer había entrado en la agenda política norteamericana a raíz de la labor desempeñada por organizaciones como la National American Woman Suffrage Association, la cual reclamaba la elaboración de una enmienda constitucional que extendiera el voto femenino a toda la nación. Con el fin de evitar el triunfo de un movimiento feminista en España, algunas publicaciones ilustraron las consecuencias que acababa generando esta situación de libertad, igualdad e independencia en los Estados Unidos. Para ello, se informaba con regularidad de los crímenes cometidos por algunas mujeres, detallando incluso el funcionamiento de las cárceles a las que iban destinadas las condenadas ${ }^{99}$. En relación a esta cuestión, el dramaturgo Gregorio Martínez Sierra ironizaba sobre las reticencias que seguía despertando la igualdad de sexos en la sociedad española:

Y las nuestras viven tan felices escribiendo al novio tulla asta la muerte, pescando marido por su linda cara, dejándose mantener por él con la mayor serenidad del mundo, perdonándole plácidamente los pecadillos de infidelidad ${ }^{100}$.

Por otra parte, las condiciones laborales también causaron enorme interés en la prensa. El obrero americano era caracterizado como un individuo interesado exclusivamente en su propia prosperidad, razón que le hacía despreocuparse de asuntos políticos y desigualdades sociales. A pesar de que la remuneración era superior a la recibida en el continente europeo, el economista Pablo de Alzola denunciaba el esfuerzo que requerían muchos trabajos

\footnotetext{
96 González Blanco, octubre de 1902: 142.

97 El Imparcial, 22 de agosto de 1905: 1. Nuestro Tiempo, agosto de 1912: 113.

98 Feinberg y Kasrils, 1976: 21-22.

99 ABC, 21 de enero de 1911: 11. Nuestro Tiempo, octubre de 1911: 96-97.

100 Martínez Sierra, 3 de noviembre de 1904: 7.
} 
y la disparidad de sueldos que existían en industrias como la siderúrgica ${ }^{101}$. El crecimiento de la economía industrial y el progreso del sindicalismo en este país provocaron una mayor conflictividad obrera, manifestada en la aparición de numerosas huelgas. Este aspecto adquirió suma relevancias en diarios como El Imparcial, donde predominaron aquellas noticias que evidenciaban los desórdenes y enfrentamientos que estaban provocando las protestas de los trabajadores estadounidenses ${ }^{102}$.

Asimismo, las percepciones españolas sobre la fuerza del socialismo en ese país fueron modificándose desde comienzos del siglo $\mathrm{XX}$, fruto de las continuas reivindicaciones que se estaban produciendo en el ámbito laboral y del éxito adquirido por el Partido Socialista de América (SPA). Tras las elecciones presidenciales de 1904, aquellos artículos que subestimaban su influencia en la clase obrera americana fueron reemplazados por otros que señalaban los temores que este movimiento estaba generando en la clase política ${ }^{103}$.

Más allá de la importancia que tenían estas cuestiones en la definición de la sociedad norteamericana, lo cierto es que la figura del millonario y sus extravagancias fue el tema más recurrente en la prensa española, pues alimentaba los tópicos de índole económica que venían perpetuándose desde el siglo XIX. De hecho, tomando como referencia el vaciado del diario $A B C$, el $19,26 \%$ de las noticias que versaban sobre los Estados Unidos se centraron en este aspecto.

La creciente polarización social era una de las características de las ciudades americanas. En contraposición a los barrios pobres y abarrotados en los que residían los inmigrantes, la nueva aristocracia corporativa, constituida por banqueros, empresarios y barones del ferrocarril, construyó impresionantes mansiones y casas de verano, al tiempo que saciaba todos sus caprichos ${ }^{104}$. Ante el interés que despertaba la clase alta de este país, prevalecieron los reportajes sobre personalidades tan conocidas como John D. Rockefeller, Andrew Carnegie o J. P. Morgan, señalando con constantes exageraciones sus grandes fortunas: «Mr. Carnegie no puede agotar su renta diaria aun cuando extendiese cada minuto un cheque de cinco libras a todo el que lo solicitara» ${ }^{105}$.

101 Alzola, marzo de 1903: 71.

102 El Imparcial, 7 de mayo de 1899: 1; 4 de septiembre de 1904:1; 14 de agosto de 1907: 1

103 Nuestro Tiempo, 25 de agosto de 1905: 57-61; 10 de abril de 1907: 61-62. ABC, 24 de marzo de 1907: 2.

104 Jones, 1996: 306. Para un mayor conocimiento sobre el surgimiento de esta aristocracia corporativa: Brands, 2010.

105 Nuestro Tiempo, mayo de 1901: 127. 
A su vez, se recurría a artículos sensacionalistas que informaban sobre la celebración de matrimonios de conveniencia, las desgracias que sufrían algunas familias adineradas o la ignorancia que reflejaban muchos ricos al derrochar su dinero. Así, por ejemplo, la revista Nuevo Mundo revelaba que una millonaria estadounidense había encargado la construcción de una catedral con la expresa condición de terminarla en un año: «Pensará que si nuestros antepasados tardaron años y años en construir asombrosos templos [...], fue sólo porque no tenían a mano las riadas de oro necesarias» ${ }^{106}$. Otro caso llamativo fue el llamado «Proceso Thaw», protagonista de una larga serie de titulares desde 1906. Tras conocer la infidelidad cometida por su esposa, Harry Thaw decidió acabar con la vida de su amante, el arquitecto Stanford White, en un restaurante de Nueva York. A lo largo de los años, las revelaciones de este crimen fueron utilizadas por la prensa con la intención de retratar la depravación moral de la sociedad americana: divorcio, testigos sobornados, persecuciones policiales, intentos de suicidio, etc. ${ }^{107}$.

A pesar de la difusión de estas imágenes negativas, muchos textos resaltaron la beneficencia de algunos millonarios, considerando que su generosidad revitalizaba el funcionamiento de las instituciones estadounidenses ${ }^{108}$. Estas valoraciones sobre los efectos positivos de la filantropía eran coincidentes con las expresadas desde otros países, en los que ésta era vista como un claro reflejo de «la necesidad actual de establecer una organización constructiva en el esquema social» ${ }^{109}$.

En último lugar, las publicaciones españolas también proyectaron una imagen de los Estados Unidos como un país peligroso, donde los ladrones quedaban impunes y la policía estaba corrompida. Debido a los altos índices de criminalidad, las noticias denunciaban los ataques injustificados que recibían los inmigrantes en ciudades como Nueva York, al considerarles responsables de los robos, asesinatos o violaciones que se producían en las calles ${ }^{110}$. Análogamente, se aludía a aquellos atentados cometidos por locos homicidas u organizaciones terroristas como la Mano Negra ${ }^{111}$.

En medio de este ambiente de pánico y miedo, uno de los sucesos que más impacto causaron fue el escándalo de la industria cárnica de Chicago,

106 Nuevo Mundo, 9 de noviembre de 1905: 6.

107 La Época, 30 de junio de 1906: 1. La Correspondencia de España, 9 de enero de 1908: 1.

108 Subirana, 3 de junio de 1911: 4-5.

109 Frankel, 2007: 108.

110 La Lectura, septiembre de 1907: 142-143.

111 El Imparcial, 2 de mayo de 1909: 1. 
aspecto al que contribuyó la difusión de la obra de Upton Sinclair (La Jungla, 1906) en las páginas del periódico El Imparcial. Si bien las revelaciones de este periodista se sumaban a las realizadas por otros compañeros -Lincoln Steffens, Ida M. Tarbell, Ray Stannard, etc.- con el objetivo de impulsar reformas progresistas que limitaran los males del país ${ }^{112}$, la prensa española abordó exclusivamente esta polémica desde un punto de vista excéntrico: "Aunque aquellos productos alimenticios, según los anuncios, estaban elaborados con carne de puerco, no había en ellos más puerco que el respectivo fabricante» ${ }^{113}$. Del mismo modo, la sociedad española era consciente de los fraudes de algunas compañías y de las malversaciones que imperaban dentro de la clase política114. Sin duda, una visión que ponía en duda el buen funcionamiento del modelo americano.

\section{CONCLUSIONES}

El presente trabajo ha abordado las percepciones españolas que circulaban sobre los Estados Unidos entre 1898 y 1914. La aproximación analítica a las fuentes seleccionadas permite vislumbrar cómo la prensa se convirtió en uno de los principales canales por los que se transmitían impresiones en torno a la potencia americana. Su estudio contribuye a contrarrestar algunas ideas que todavía se mantienen vigentes en el ámbito académico, como el escaso interés por la alta cultura norteamericana o el recelo que generaba la figura de Theodore Roosevelt en la opinión pública española.

Analizados aquellos principales temas en torno a los que se articulaban las referencias a este país, estamos en condiciones de afirmar que las imágenes proyectadas no fueron tan diferentes a las concebidas en países como Inglaterra o Francia. Más allá de la aparición de algunos rasgos particulares como consecuencia de la guerra hispano-norteamericana de 1898 y de las propias circunstancias nacionales, la visión que se generó sobre los Estados Unidos estuvo condicionada por las opiniones que se estaban forjando en Europa. Un planteamiento que queda respaldado tras valorar la constante traducción de artículos pertenecientes a publicaciones extranjeras, la difusión de viñetas de procedencia foránea -Le Rire, Daily Mirror, Punch, etc.-, la estrecha colaboración de periodistas británicos y franceses en determinadas revistas o la

112 La obra The Bully Pulpit aborda la estrecha colaboración del presidente Theodore Roosevelt con este grupo de periodistas. Goodwin, 2013.

113 Gedeón, 10 de junio de 1906: 8.

114 Araujo, febrero de 1906: 177. 
traducción de diarios de viaje como el del periodista Jules Huret (En América. De Nueva York a Nueva Orleans, 1905). Además, se produjo una traslación y continuación de diversos debates que estaban teniendo lugar fuera de nuestras fronteras, especialmente la polémica que suscitó la lucha iniciada por el presidente Roosevelt contra los trusts.

Junto a estas afirmaciones, conviene matizar dos temas de gran relevancia para esta investigación: la homogeneidad y la recepción de estas impresiones sobre los Estados Unidos. A la hora de identificar a los autores de estos textos, destaca un perfil indefinido. Junto a la presencia de periodistas, la participación de un amplio abanico de intelectuales, políticos y expertos provocó que estas imágenes no estuvieran condicionadas por una ideología política concreta. Los contactos y experiencias comunes entre este grupo de personalidades crearon una serie de redes que se superpusieron a cualquier identidad individual y se convirtieron en canales de circulación de unas mismas ideas y formas de representación; aspecto respaldado en menor medida por la monopolización del mercado informativo por parte de las agencias internacionales, que produjeron una uniformidad en las noticias extranjeras. No obstante, esto no significa que no existieran desavenencias ante ciertas cuestiones. Así, por ejemplo, la fascinación que despertaron las instituciones políticas durante los primeros años del siglo XX contrastó con varios comentarios que seguían señalando los límites de este sistema democrático.

Por otro lado, resulta difícil concluir qué influencia tuvieron estas percepciones en la población española. Aunque la prensa se convirtió en la vía principal para conocer otros territorios, nunca se consolidó un modelo de periodismo de masas, por lo que el impacto de estas publicaciones siguió siendo minoritario a lo largo de este período. A su vez, las altas tasas de analfabetismo revelan que su alcance fue mínimo en los estratos inferiores de la sociedad, cuya visión sobre la potencia americana se basaba en aquellas experiencias, opiniones o noticias que llegaban por transmisión oral y que apenas dejaron testimonios escritos que sirvan para cubrir esta amplia laguna historiográfica en la actualidad. Todo ello provocó que la lectura de periódicos y revistas nacionales sólo estuviera al alcance de las clases medias y altas, destacando la esfera política e intelectual.

A pesar de la existencia de algunas limitaciones, la necesidad de este tipo de trabajos sigue siendo fundamental, pues puede ser de utilidad para futuras investigaciones que pretendan establecer una estrecha relación entre cultura y poder, analizando cómo el peso de ciertos prejuicios y estereotipos sobre los Estados Unidos determinaron las relaciones establecidas entre España y este país a lo largo del siglo XX. Por último, queda pendiente que proyectos venideros esclarezcan cómo los escritos sobre la potencia americana estuvieron 
condicionados por la población receptora, la cual no dudó en instrumentalizar muchas de las noticias difundidas en función de sus propios intereses. Las impresiones que circulaban sobre esta nación ayudaron a alimentar muchos de los debates nacionales que se estaban manteniendo en ese momento, como la deficiente situación de la ciencia y la educación; o sirvieron para reforzar la identidad de la sociedad española y su vínculo con Europa.

\section{BIBLIOGRAFÍA}

\section{Artículos comentados de los colaboradores}

Alfaro, Agustín, "La vida en Nueva York", $A B C$, X/3.296 (26 de junio de 1914): 3-4. Alzola, Pablo de, "Colectivismo y reformas sociales", Nuestro Tiempo, 27 (marzo de 1903): 56-73.

Araujo, Fernando, "Revista de revistas. El child-study movement en los Estados Unidos", La España Moderna, 147 (marzo de 1901): 191-196.

Araujo, Fernando, "Revista de revistas. Instituciones escolares de los Estados Unidos", La España Moderna, 147 (marzo de 1901): 184-188.

Araujo, Fernando, "Revista de revistas. La fortuna de Edgardo Poe", La España Moderna, 171 (marzo de 1903): 190.

Araujo, Fernando, "Revista de revistas. La vida de las mujeres en los Estados Unidos", La España Moderna, 173 (mayo de 1903): 171-176.

Araujo, Fernando, "Revista de revistas. La higiene en las escuelas públicas", La España Moderna, 179 (noviembre de 1903): 198-199.

Araujo, Fernando, "Revista de revistas. Cómo se crea el tipo americano", La España Moderna, 180 (diciembre de 1903): 191-192.

Araujo, Fernando, "Revista de revistas. Impresiones de un viaje por los Estados Unidos", La España Moderna, 189 (septiembre de 1904): 206.

Araujo, Fernando, "Revista de revistas. El gran sacerdote del Sol en Chicago", La España Moderna, 193 (enero de 1905): 193-197.

Araujo, Fernando, "Revista de revistas. El humorismo americano: Marco Twain", La España Moderna, 197 (mayo de 1905): 191-197.

Araujo, Fernando, "Revista de revistas. Un siglo de literatura femenina en los Estados Unidos", La España Moderna, 202 (octubre de 1905): 191-195.

Araujo, Fernando, "Revista de revistas. La corrupción en los Estados Unidos", $L a$ España Moderna, 206 (febrero de 1906): 175-178. 
Araujo, Fernando, "Revista de revistas. Whistleriana", La España Moderna, 238 (octubre de 1908): 196-198.

Araujo, Fernando, "Revista de revistas. Mark Twain”, La España Moderna, 259 (julio de 1910): 202-204.

Araujo, Fernando, "Revista de revistas. Las transformaciones de la publicidad", La España Moderna, 284 (agosto de 1912): 190-199.

Araujo, Fernando, "Revista de revistas. La novela policíaca, de Edgar Poe a Nick Carter”, La España Moderna, 287 (noviembre de 1912): 170-178.

Araujo, Fernando, "Revista de revistas. La Eugénica", La España Moderna, 302 (febrero de 1914): 161-164.

Aznar, Severino, "Revista de revistas. Roosevelt", Nuestro Tiempo, 11 (noviembre de 1901): 97-102.

Brouta, Julio, "Tesores españoles en Yankilandia. El Museo Hispánico en Nueva York", La España Moderna, 243 (marzo de 1909): 84-91.

Cadenas, José Juan, “ABC en París. La Fanciulla del West”, ABC, VI/2.017 (17 de diciembre de 1910): 4-5.

Canals, Salvador, "El mes pasado. Mac-Kinley y Roosevelt", Nuestro Tiempo, 10 (octubre de 1901): 1-7.

Cavia, Mariano de, “Lo baila usted o no lo baila?”, El Imparcial, XLIV/15.446 (9 de marzo de 1910): 1.

Cubillo, L., "La elección presidencial en los Estados Unidos", Nuestro Tiempo, 46 (octubre de 1904): 83-96.

Gabaldón, Luis, "Los animales en las elecciones", $A B C, I V / 1.122$ (2 de julio de 1908): 10.

Gómez de Baquero, Eduardo, "Revista literaria. Libros extranjeros", El Imparcial, XXXVII/13.051 (3 de agosto de 1903): 5.

González Blanco, Edmundo, "La ley del divorcio y sus inconvenientes", La España Moderna, 166 (octubre de 1902): 114-171.

Guerra, Ángel, "El centenario de Edgard Allan Poe”, La España Moderna, 244 (abril de 1909): 130-144.

Guerra, Ángel, “Literatura contemporánea. Walt Whitman”, La España Moderna, 270 (junio de 1911): 5-27.

Juderías, Julián, "La prensa en los Estados Unidos”, Nuestro Tiempo, 157 (enero de 1912): 79-87.

Martínez Sierra, Gregorio, "Feminismos”, $A B C$, II/133 (3 de noviembre de 1904): 7.

Mora, Francisco, "Postales europeas. El premio del pacifismo", ABC, II/58 (17 de agosto de 1906): 6. 
Pazos y García, Diego, "Sobre la doctrina social de Henry George y su trascendencia financiera", Nuestro Tiempo, 168 (diciembre de 1912): 1-29.

Pérez de Ayala, Ramón, "De los Estados Unidos. Historia de las cosas pequeñas, I", El Imparcial, XLVIII/16.855 (24 de enero de 1914): 2.

Pérez de Ayala, Ramón, "De los Estados Unidos. Historia de las cosas pequeñas, II", El Imparcial, XLVIII/16.857 (26 de enero de 1914): 1.

Pérez de Ayala, Ramón, "De los Estados Unidos. Historia de las cosas pequeñas, IV", El Imparcial, XLVIII/16.861 (30 de enero de 1914): 1.

Pérez de Ayala, Ramón, "Roosevelt y nuestra guerra”, El Imparcial, XLVIII/16.945 (25 de abril de 1914): 3 .

Rubiano, Santos, "Revista de revistas. Los negros en América del Norte", Nuestro Tiempo, 80 (25 de julio de 1906): 68.

Sawa, Alejandro, "Dos recuerdos del rayo y de la gloria", El Imparcial, XLII/14.692 (10 de febrero de 1908): 3 .

Subirana, Luis, "Las grandes obras de la filantropía", $A B C$, VII/2.183 (3 de junio de 1911): 4-5.

Terán, Luis de, "Revista bibliográfica. Cher les heureux du monde, por Edith Wharton", Nuestro Tiempo, 133 (enero de 1910): 114-115.

Unamuno, Miguel de, "El canto adámico", El Imparcial, XL/14.142 (6 de agosto de 1906): 3.

Vergara, Gabriel María, "El imperio del trust", Revista Contemporánea, CXXXIV/3 (marzo de 1907): 271-273.

2. Monografias, capitulos de libros y artículos

Ball, Alan, Imagining America. Influences and Images in Twentieth-Century Russia, Lanham, Rowman and Littlefield, 2003.

Brands, H. W., American Colossus. The Triumph of Capitalism, 1865-1900, New York, Doubleday, 2010.

Broughton, Morris, "From South Africa", Franz M. Joseph y Raymond Aron (eds.), As Others See U.S.: The United States through Foreign Eyes, Princeton, Princeton University Press, 1959: 258-269.

Chandler, Alfred D., "The United States: Evolution of Enterprise", Peter Mathias y M. M. Postan (eds.), The Cambridge Economic History of Europe, Cambridge, Cambridge University Press, 1978, vol. 7, part 2: 70-133.

Commager, Henry Steele, America in Perspective. The United States through Foreign Eyes, New York, Random House, 1947. 
Diner, Dan, America in the Eyes of the Germans. An Essay of Anti-Americanism, Princeton, Markus Wiener, 1996.

Ellwood, David W., The Shock of America. Europe and the Challenge of the Century, Oxford, Oxford University Press, 2012.

Feinberg, Barry y Kasrils, Ronald (eds.), La América de Bertrand Russell, 1896-1945, Madrid, Taurus, 1976.

Fernández de Miguel, Daniel, El enemigo yanqui. Las raíces conservadoras del antiamericanismo español, Zaragoza, Genueve Ediciones, 2012.

Frankel, Robert, Observing America. The Commentary of British Visitors to the United States, 1890-1950, Madison, University of Wisconsin Press, 2007.

García Montón, Isabel, Viaje a la modernidad: la visión de los Estados Unidos en la España finisecular, Madrid, Ed. Verbum, 2002.

García Muñoz, César, Historia de un estereotipo. Intelectuales españoles en Estados Unidos (1885-1936), Madrid, Langre, 2008.

Gienow-Hecht, Jessica C. E., "Shame on U.S.? Academics, Cultural Transfer, and the Cold War - A Critical Review", Diplomatic History, XXIV/3 (Oxford, 2000): 465-494.

Gienow-Hecht, Jessica C. E., Sound Diplomacy. Music and Emotions in Transatlantic Relations, 1850-1920, Chicago, University of Chicago Press, 2009.

Goodwin, Doris Kearns, The Bully Pulpit. Theodore Roosevelt, William Howard Taft, and the Golden Age of Journalism, New York, Simon \& Schuster, 2013.

Guerlain, Pierre, Miroirs Transatlantiques. La France et les États-Unis entre Passions et Indifférences, Paris, L'Harmattan, 1996.

Hofstadter, Richard, The Age of Reform. From Bryan to FDR, New York, Vintage Books, 1955.

Iriye, Akira, Cultural Internationalism and World Order, Baltimore, Johns Hopkins University Press, 1997.

Jones, Maldwyn A., Historia de Estados Unidos, 1607-1992, Madrid, Cátedra, 1996.

Kevles, Daniel J., “Las instituciones científicas americanas, 1890-1930. La organización de la ciencia en una cultura práctica y pluralista", José María Sánchez Ron (coord.), 1907-1987. La Junta para la Ampliación de Estudios e Investigaciones Científicas 80 años después. vol. 1, Madrid, CSIC, 1988: 209-228.

Martínez de las Heras, Agustín, "La visión de los Estados Unidos durante la Guerra del 98 desde las crónicas semanales de la Lectura Dominical", Carmen Flys y Juan E. Cruz (eds.), El nuevo horizonte. España / Estados Unidos. El legado de 1848 y 1898 frente al nuevo milenio, Madrid, Universidad de Alcalá, 2001: 97-114. 
Menand, Louis, The Metaphysical Club. A Story of American Ideas, New York, Farrar, Straus and Giroux, 2001.

Montero Jiménez, José Antonio, "Las relaciones hispano-norteamericanas en los años de la Primera Guerra Mundial", Cuadernos de Historia Contemporánea, 26 (Madrid, 2004): 23-47.

Ngai, Mae, Impossible Subjects. Illegal Aliens and the Making of Modern America, Princeton, Princeton University Press, 2003.

Niño, Antonio, "Las relaciones culturales como punto de reencuentro hispano-estadounidense", Lorenzo Delgado y María Dolores Elizalde (eds.), España y Estados Unidos en el siglo XX, Madrid, CSIC, 2005: 57-94.

Norton, Mary Beth, Katzman, David M. et. al., A People and a Nation. A History of the United States, Boston, Houghton Mifflin, 1986.

Portes, Jacques, Fascination and Misgivings. The United States in French Opinion, 1870-1914, New York, Cambridge University Press, 2000.

Robles Muñoz, Cristóbal, 1898. Diplomacia y opinión, Madrid, CSIC, 1991.

Sánchez Aranda, José Javier y Barrera del Barrio, Carlos, Historia del periodismo español. Desde sus orígenes hasta 1975, Pamplona, EUNSA, 1992.

Schulze, Ingrid, "1898: Apuntes sobre la diplomacia internacional y la opinión pública", Historia y Comunicación Social, 3 (Madrid, 1998): 223-238.

Scott-Smith, Giles, Networks of Empire. The U.S. State Department's Foreign Leader Program in Netherlands, France, and Britain 1950-1970, Brussels, Peter Lang, 2008.

Seoane, María Cruz y Sáiz, María Dolores, Historia del periodismo en España. Vol. 3, El siglo XX, 1898-1936, Madrid, Alianza, 1998.

Seregni, Alessandro, El antiamericanismo español, Madrid, Síntesis, 2007.

Sevilla, Rosario, "España y Estados Unidos: 1898, impresiones del derrotado", Revista de Occidente, 202-203 (Madrid, 1998): 278-293.

Vílchez de Arribas, Juan Fermín, Historia gráfica de la prensa española (1758-1976), Barcelona, RBA, 2012.

Wiebe, Robert, The Search for Order, 1877-1920, New York, Hill and Wang, 1967.

Woodward, C. Vann, The Old World's New World, New York, Oxford University Press, 2000.

Fecha de recepción: 12 de febrero de 2015.

Fecha de aceptación: 8 de mayo de 2015. 


\section{Reflections on the Future Present. Images of the United States in the Early Twentieth-Century Spanish Press (1898-1914)}

This article focuses on Spanish perceptions of the United States between 1898 and 1914 with an exhaustive perusal of some of the major publications of that period. Establishing a range of common themes -culture, scientific and technological development, politics and society - the author demonstrates that the Spanish vision was not very different from that of other countries, because it was influenced by the views and opinions expressed in Europe. Furthermore, the establishment of an extensive network of contacts with the editorial offices of newspapers and periodicals served as a channel for the circulation of a set of common ideas and representations of American power.

KeY WORDS: Spain; the United States; $20^{\text {th }}$ century; press; perception; image. 